\title{
Shared care in mental illness: A rapid review to inform implementation
}

Brian J Kelly ${ }^{1 * \dagger}$, David A Perkins ${ }^{3+}$, Jeffrey D Fuller ${ }^{2+}$ and Sharon M Parker ${ }^{3+}$

\begin{abstract}
Background: While integrated primary healthcare for the management of depression has been well researched, appropriate models of primary care for people with severe and persistent psychotic disorders are poorly understood. In 2010 the NSW (Australia) Health Department commissioned a review of the evidence on "shared care" models of ambulatory mental health services. This focussed on critical factors in the implementation of these models in clinical practice, with a view to providing policy direction. The review excluded evidence about dementia, substance use and personality disorders.

Methods: A rapid review involving a search for systematic reviews on The Cochrane Database of Systematic Reviews and Database of Abstracts of Reviews of Effects (DARE). This was followed by a search for papers published since these systematic reviews on Medline and supplemented by limited iterative searching from reference lists.
\end{abstract}

Results: Shared care trials report improved mental and physical health outcomes in some clinical settings with improved social function, self management skills, service acceptability and reduced hospitalisation. Other benefits include improved access to specialist care, better engagement with and acceptability of mental health services. Limited economic evaluation shows significant set up costs, reduced patient costs and service savings often realised by other providers. Nevertheless these findings are not evident across all clinical groups. Gains require substantial cross-organisational commitment, carefully designed and consistently delivered interventions, with attention to staff selection, training and supervision. Effective models incorporated linkages across various service levels, clinical monitoring within agreed treatment protocols, improved continuity and comprehensiveness of services.

Conclusions: "Shared Care" models of mental health service delivery require attention to multiple levels (from organisational to individual clinicians), and complex service re-design. Re-evaluation of the roles of specialist mental health staff is a critical requirement. As expected, no one model of "shared" care fits diverse clinical groups. On the basis of the available evidence, we recommended a local trial that examined the process of implementation of core principles of shared care within primary care and specialist mental health clinical services.

\section{Background}

In 2008 the New South Wales (Australia) Government's Mental Health Sentinel Events Committee published its fourth report which concluded: "a definitive set of best practice standards to guide the development and implementation of shared care for mental health consumers is

\footnotetext{
* Correspondence: Brian.Kelly@newcastle.edu.au

† Contributed equally

'Centre for Brain and Mental Health Research, School of Medicine and Public Health, Faculty of Health University of Newcastle, University Drive, Callaghan 2308, Australia

Full list of author information is available at the end of the article
}

lacking" [1]. This Committee found cases of homicide and suicide where patients had been "under some form of shared care arrangement" but with no effective system to ensure oversight and take action where necessary. This report was referred to the New South Wales Government Department of Health and via brokerage with The Sax Institute, Sydney NSW, an expert evidence check or rapid review was commissioned.

The authors were contracted to conduct the review. This included negotiation of the research questions, presentation of preliminary scoping, draft and revised final reports. Questions and clarification were addressed via

\section{() Biomed Central}


consultation involving all parties throughout the process. This form of knowledge exchange has been described as "the problem solving, policy driven model" but it might equally operate through a process of enlightenment by which evidence and ideas permeate the policy making system [2]. Rapid reviews are a new and contentious approach to knowledge transfer and exchange between researchers and policy makers. They are typically conducted in months rather than years and the focus is determined by policy-makers rather than researchers. The strength of a rapid review lies in its timeliness and responsiveness to the needs of policy makers and practitioners, but its limitations include the reliability and generalisability of the findings [3]. It has been argued that rapid reviews provide local guidance and are useful resources in the later development of a traditional systematic review [4]. To provide timely and responsive advice the search process is accelerated and the findings of existing systematic reviews emphasised, but some harder to find material in the grey literature may be missed. This may introduce biases and it has been suggested that rapid reviews should carry a warning to the effect that guidance may be revised if and when a relevant systematic review is published [5].

There is increasing recognition that improving the detection, treatment and outcomes for mental health problems requires service models that integrate mental health care within primary health care practice [6]. While much of the research to date has focussed on primary care management of depression [7], the complex needs of people with more severe and persistent mental illness has received less attention. Despite the achievements of a well-established tradition of general hospital based consultation-liaison psychiatry (comprising consultation, specialist support, collaboration and joint care) there is only limited evidence for the translation of these principles to community ambulatory and primary care [7]. Although sometimes referred to as "consultationliaison services in primary care" [8] these models of "shared care" are often poorly defined, ranging from the simple transfer of care from one provider to another, to the involvement of one or more services in patient care, through to formalised cross-service arrangements [9].

The rapid review was undertaken to investigate the evidence underpinning "shared care" in ambulatory mental health care. The focus related mainly to adults with severe and persistent mental disorders. Evidence regarding treatment models for a broader range of conditions (e.g. dementia, substance use disorders, or personality disorder) was outside the scope of this review.

The review addressed the following questions:

1. Does "Shared Care" improve clinical outcomes for people with mental illness?
2. If so, what are the proposed ingredients of an effective "Shared Care" program?

The latter required hypothesising a proposed set of such ingredients based on a synthesis of the literature.

\section{Methods}

The research team comprised a psychiatrist with research, clinical and teaching responsibilities, a nursing academic with research and clinical experience in mental health services, a health systems researcher specialising in mental health and primary health care and an information scientist with mental health nursing experience. The group had recently completed a 12 month narrative review of effective service linkages in primary mental health care [10] were familiar with the literature and had established working arrangements. They also had many years of experience with the NSW health care system and brought a strong understanding of service and political context.

Shared care covers a broad spectrum of collaborative treatment arrangements and there is no standard definition in the literature $[11,12]$. For the purposes of this rapid review, we developed the following definition based on the published literature:

A structured system for achieving integration of care across multiple autonomous providers and services [13] with both primary and secondary care practitioners contributing to elements of a patient's overall package of care [9]. Shared care involves some agreement about the shared activities and levels of responsibility for each provider and appropriate communication processes to support this integration. A shared care arrangement may involve any combination of government, non-government or private sector providers.

As a rapid review, the initial step was to identify systematic reviews and examine their relevance. This was followed by a search for papers published subsequent to these systematic reviews as well as iterative searching from reference lists for any outstanding published works. The search for systematic reviews was conducted in the Cochrane Database of Systematic Reviews and Database of Abstracts of Reviews of Effects (DARE) (2004-2010). A comprehensive search strategy was developed and applied to Medline (Additional file 1). One person (SP) assessed each title and abstract against the inclusion and exclusion criteria (Additional file 2) and consulted with a second author where there was any uncertainty. Focussed data extraction was undertaken and extracted material discussed and explored during project meetings. 
We found six systematic reviews of shared or collaborative care that included people with a mental disorder [10,11,14-17], several covered depression in some depth [10,15-19]. We then reviewed 271 citations from the black search of which 23 dealt with mental health conditions other than adult depression. We included 12 studies of severe or persistent mental illness (21 citations). Two addressed bi-polar disorder [20,21], nine severe or chronic mental illness [22-29], and one first episode psychosis [30].

\section{Results}

\section{Does shared care work?}

The benefits of shared care models are summarised in Table 1 . The highest quality evidence (level 4) [31] comes from US and UK studies of the treatment of mental disorders in primary care, such as depression and anxiety (often in the context of coexisting physical conditions such as diabetes, cancer or cardiovascular disease). These trials mainly recruited those aged 60 or over [32,33].

\section{Depression and other common mental disorders}

Smith [11] undertook a detailed meta-analysis examining 20 studies of shared care for chronic disease management, six of which examined shared care for depressive disorders and 3 persistent mental illness, the remainder investigating a range of shared care interventions for chronic physical conditions. The most consistent finding was in prescribing and drug treatment adherence in favour of shared care interventions. The six studies of shared care for depression alone reported evidence of benefits in rates of recovery or remission [33-38]. Nevertheless, Smith drew the sobering conclusion that overall "consistent evidence for the

Table 1 Evidence for the benefits of shared care

\begin{tabular}{|c|c|}
\hline Benefit & Supporting evidence \\
\hline \multirow[t]{4}{*}{ Access and Equity } & $\begin{array}{l}\text { - Improved access by reducing barriers to availability of integrated care with primary care or improved access to } \\
\text { specialist care (Druss 2001, Harrison-Read 2002, PRISM-E, van Orden 2009). }\end{array}$ \\
\hline & $\begin{array}{l}\text { - Improved access to outpatient services, rehab services, and an increase the number of people receiving follow-up, } \\
\text { case management and review of their medication (Byng 2004, Gilmer 2010, Rosenheck 2003) }\end{array}$ \\
\hline & $\begin{array}{l}\text { - Increased ability to target high priority groups through tailored programs linked with relevant services (e.g. cultural } \\
\text { groups, age-based services, homelessness) (Asanow 2009, Gilmer 2010, Rosenheck 2003) }\end{array}$ \\
\hline & • Reduced impact of perceived stigma on help seeking for mental health problems (PRISM-E, Gavin 2008) \\
\hline \multirow[t]{2}{*}{ Acceptability and stigma } & - Reduced unmet need for treatment (PRISM-E (73\% of participants)) \\
\hline & • Improved cultural appropriateness of service (IMPACT, PRISM-E) \\
\hline \multirow[t]{8}{*}{ Comprehensiveness } & $\begin{array}{l}\text { - Increased efficacy of pharmacological/psychological treatments in primary care. Treatment course is generally } \\
\text { predictable and with good step up/step down algorithms (IMPACT, PROSPECT,CALM, Bower 2006, Gilbody 2006)) }\end{array}$ \\
\hline & • Capacity to match intensity of intervention to patient need (stepped care) (IMPACT, PROSPECT, CALM) \\
\hline & - Improved capacity of generalist services to meet full range of patient needs (IMPACT, PRISM-E) \\
\hline & - Improved communication between levels of care (primary and specialist) (Craven 2006, PRISM-E) \\
\hline & $\begin{array}{l}\text { - Improved capacity to address mental health aspects of physical illness and chronic disease (Byng 2004, Druss 2001, } \\
\text { Gilmer 2010, Rosenheck 2003, PRISM-E, IMPACT) }\end{array}$ \\
\hline & • Improved skill of generalist health worker in mental health care (Fuller 2009) \\
\hline & - Considers client preference in the choice of care delivered (IMPACT, CALM) \\
\hline & • Promotes engagement in care (e.g. via link worker) (Byng 2004, Oxman 2003) \\
\hline Continuity & - Single point of contact to review care progress and needs (e.g. through primary care) (Druss 2001, PRISM-E) \\
\hline \multirow[t]{7}{*}{$\begin{array}{l}\text { Outcomes: clinical, } \\
\text { functional. social }\end{array}$} & $\begin{array}{l}\text { - Evidence of improved clinical outcomes (psychiatric) (Bauer 2006, Bertelsen 2008, Bower 2006, Fuller 2009, Gilbody } \\
\text { 2006, Simon 2006, PRISM-E (6 mths only), IMPACT, PROSPECT, RESPECT-D, CALM) }\end{array}$ \\
\hline & • Evidence of improved clinical outcomes (physical and medical) (Druss 2001, IMPACT) \\
\hline & • Evidence of reduced hospitalisation for mental health problem (Bauer 2009) \\
\hline & - Evidence of improved social functioning and/or quality of life (Bauer 2009, Gilmer 2010, Rosenheck 2003, IMPACT) \\
\hline & $\begin{array}{l}\text { - Greater satisfaction with care (Asarnow } 2009 \text { ( } 6 \text { months), Bauer 2009, Gilmer 2010, Rosenheck 2003, PRISM-E, } \\
\text { IMPACT, RESPECT-D) }\end{array}$ \\
\hline & • Increased ability of consumers to manage their own care (IMPACT) \\
\hline & • Reduced or equal client costs (Bauer 2006, Bower 2006, Druss 2001, Katon 2002, van Orden 2009) \\
\hline \multirow[t]{4}{*}{ Cost $^{1}$} & $\begin{array}{l}\text { - Increased health care costs of initial set-up (first } 12 \text { months) balanced against cost savings in following year (Katon } \\
\text { 2002, Katon 2006, Simon 2007) }\end{array}$ \\
\hline & • Reduced in-patient costs (Bauer 2009, Byng 2004, Druss 2001) \\
\hline & • Cost-offset effects on non-mental health-related ambulatory care services (IMPACT) \\
\hline & - Reduction in costs to other systems (e.g. justice) (Gilmer 2010, Rosenheck 2003) \\
\hline
\end{tabular}

\footnotetext{
${ }^{1}$ Costs generally have been assessed during the intervention period only - up to 2 years follow up in large depression trials
} 
effectiveness of shared care is lacking for most of the outcomes studied". The authors go on to conclude that effectiveness may be greater for clinical subgroups, highlighting findings among patients with depressive disorders particularly.

While most studies to date have focussed on depression either alone or in combination with chronic physical illness, a recent RCT investigated a flexible treatment delivery model for collaborative primary care management of people with multiple anxiety disorders (CALM) [39]. This study demonstrated significant improvements in anxiety and depressive symptoms, functional disability and in measures of quality care.

A meta-analysis of interventions targeting improved communication strategies between primary care providers and specialists (representing a model of "shared care" for the purposes of our review) by Foy [14] found moderate overall effect sizes for a range of chronic conditions, including mental disorders (18/38 studies) with similar effect sizes across conditions. This review also found that effect size increased when analysis was restricted to studies of depression. This supports the results of meta-analyses of depression trials $[15,17]$ that have reported positive clinical outcomes, increased use and effective treatment with antidepressants and sustainable benefits for up to 5 years.

Two large US trials on collaborative care for depression (IMPACT and PRISM-E) also reported results for subgroups from ethnic minorities $[40,41]$ with both reporting similar results to the general patient population studied.

\section{Severe and persistent mental disorders}

There were fewer published papers about the benefits of "shared care" for severe and persistent mental disorders (e.g. schizophrenia) and very little work about service links outside the health sector with welfare, housing, education, or employment.

Despite a high need for health and social services for people with such persistent psychotic disorders, Fuller [10] found only 16 of 119 reviewed studies examined such services. Of the RCTs, three reported some clinical benefit including improved mental and physical function [42] improved physical function [23] and reduced relapse rate [22].RCTs by Lester and Warner [26,43] of patient-held records found no clinical or service use benefits, while a cohort study by McDonough [44] reported no clinical or service use benefit from a GPCommunity Health Team shared care register. However, an RCT by van Orden [29] found no clinical benefit from an on-site mental health worker in primary care, but reported decreased waiting time to see a mental health professional and decreased mean number of referrals for specialised mental health appointments. Other studies of co-located services have reported improved communication among providers, and increased referral to mental health services $[45,46]$.

Studies of Assertive Community Treatment (ACT) $[20,47,48]$, found no significant clinical outcomes but improved social function, quality of life and satisfaction, decreased hospitalisation and improved engagement with services. A trial by Druss [23] of veterans with severe mental illness also reported service improvements. Those receiving integrated medical and mental health care were compared with those receiving usual care in a general medicine clinic. After one year, veterans assigned to the integrated care clinic reported significantly improved access and quality of care (e.g. fewer problems in access to mental health services, greater attention to consumer preferences, courtesy, and coordination). The largest effect was in continuity of care.

Two studies of supported housing and mental health follow up using ACT principles for people with persistent and severe mental illness reported improved quality of life, better physical health, higher satisfaction and improvements in housing stability and perhaps because of this, improved treatment engagement $[24,27]$

We found no evidence of programs reporting adverse clinical outcomes.

\section{What are the necessary components of effective shared care services?}

On the basis of the existing studies, a major focus of this review was the inductive process to propose or hypothesise a set of "core ingredients" that comprise effective shared care, providing a base to inform future service development projects.

It was evident that models of shared care varied in complexity reflecting the target population, the structure and organisation of the health services in which they were located, and other local factors [49]. Shared care covered a broad spectrum of collaborative treatment arrangements, where provider involvement fluctuated depending on consumer need and so there was no single model to fit every community or situation [12]. Regrettably, while studies have demonstrated some benefits from these multi-component interventions across patient outcomes, service use and some costs, there is less evidence from such studies regarding the process of service change required to achieve these outcomes.

In general, effective collaborations were found to use multi-component strategies that reflected the following: i) the chronic and complex nature of many mental health problems, ii) the need to improve access to and engagement in treatments (e.g. through co-location of general and mental health services to lessen stigma), iii) the need to improve treatment adherence and continuation through care coordination, facilitation and monitoring [50] and iv) strategies that applied a clear set of core 
ingredients to promote service collaboration but with capacity for flexibility to local needs and context [51]. Without differentiating between the type of mental illness, Fuller [10] identified that most trials with positive clinical, service use or economic outcomes employed multiple linkage strategies that include some "direct collaborative activity", "guideline initiated care" and "a communication system". For the purpose of this review we have tabulated five of the major international studies on shared care for depression and anxiety (Table 2 ) and twelve for severe and persistent mental illness (Table 3 and Table 4) in an attempt to examine the common components of such interventions across these studies. Common components across both the depression/anxiety and severe and persistent mental illness studies are case management and care coordination roles (chiefly with mental health expertise), clinical supervision, follow up and use of standard outcome measures. Treatment algorithms were most evident in the depression/anxiety studies but not in the studies of persistent mental illness. The use of specific strategies targeting enhanced communication between providers is particularly evident in the persistent mental illness studies.

Based on a synthesis of these findings, the following discussion proposes specific elements of effective shared care services while acknowledging this complexity and the overlap of these elements.

\section{Clarity of Intervention}

Studies demonstrating improved outcomes for depression and anxiety using "shared care" in primary care

Table 2 The core components of effective shared care models for depression and anxiety

\begin{tabular}{|c|c|c|c|c|c|}
\hline $\begin{array}{l}\text { Process of } \\
\text { care }\end{array}$ & $\begin{array}{l}\text { PRISM-E } \\
\text { Integrated } \\
\text { mental } \\
\text { health } \\
\text { service }\end{array}$ & $\begin{array}{l}\text { MPACT I } \\
\text { Care manager (nurses } \\
\text { or psychologists } \\
\text { trained for the study }\end{array}$ & $\begin{array}{l}\text { PROSPECT } \\
\text { Care manager } \\
\text { (depression } \\
\text { care manager) }\end{array}$ & $\begin{array}{l}\text { RESPECT-D } \\
\text { Care manager } \\
\text { (background in PC } \\
\text { or MH nursing) }\end{array}$ & $\begin{array}{l}\text { CALM } \\
\text { Flexible treatment delivery model (preferred } \\
\text { treatment) Anxiety Care Specialist (ACS) to } \\
\text { deliver web based CBT program }\end{array}$ \\
\hline Screening & yes & yes & yes & no & yes \\
\hline $\begin{array}{l}\text { Treatment } \\
\text { algorithm }\end{array}$ & no & yes & yes & no & yes \\
\hline $\begin{array}{l}\text { Formal } \\
\text { stepped care }\end{array}$ & no & yes & yes & no & yes \\
\hline $\begin{array}{l}\text { Care } \\
\text { management } \\
\text { location }\end{array}$ & na & on-site & on-site & $\begin{array}{c}\text { off-site (centrally } \\
\text { located) }\end{array}$ & on-site \\
\hline $\begin{array}{l}\text { Patient } \\
\text { education/self } \\
\text { management }\end{array}$ & variable & yes & yes & yes & yes \\
\hline $\begin{array}{l}\text { Case } \\
\text { management }\end{array}$ & yes & yes & yes & yes & yes \\
\hline $\begin{array}{l}\text { Care } \\
\text { management } \\
\text { to patient } \\
\text { contact }\end{array}$ & na & face-to-face; telephone & face-to-face & telephone & face-to-face \\
\hline $\begin{array}{l}\text { Psychiatric } \\
\text { supervision }\end{array}$ & na & face-to-face; telephone & face-to-face & telephone & telephone/email \\
\hline $\begin{array}{l}\text { Care } \\
\text { management } \\
\text { counselling }\end{array}$ & na & PST-PC & IPT & supportive & supportive \\
\hline $\begin{array}{l}\text { Psychological } \\
\text { supervision }\end{array}$ & na & telephone & face-to-face & na & unclear \\
\hline $\begin{array}{l}\text { MH specialty } \\
\text { treatment } \\
\text { location }\end{array}$ & on-site & on-site & on-site & off-site & on-site \\
\hline $\begin{array}{l}\text { Geriatrician } \\
\text { supervision }\end{array}$ & no & Liaison/PC provider & no & no & no \\
\hline $\begin{array}{l}\text { Standardised } \\
\text { follow up }\end{array}$ & yes & yes & yes & yes & yes \\
\hline $\begin{array}{l}\text { Standardised } \\
\text { outcome } \\
\text { measure }\end{array}$ & yes & yes & yes & yes & yes \\
\hline
\end{tabular}

Source: Oxman -The American Journal of Geriatric Psychiatry 2003; 11, 5- (Table 2, Page 509)

Butler - AHRQ Publication No. 09-E003. Rockville, MD. Agency for Healthcare Research and Quality. 2008 (Table 4, Page 46)

Roy-Byrne - Delivery of Evidence-Based Treatment for Multiple Anxiety Disorders in Primary Care. A Randomized Controlled Trial JAMA 2010;303,19. 
Table 3 The core components of shared care models for severe and persistent mental disorders

\begin{tabular}{|c|c|c|c|c|c|c|}
\hline & $\begin{array}{c}\text { COPERATIVE STUDIES } \\
\text { PROGRAM } 430 \text { Bauer } \\
2009\end{array}$ & Simon 2006 & $\begin{array}{l}\text { OPUS Bertelson } \\
2008\end{array}$ & $\begin{array}{l}\text { MENTAL HEALTH } \\
\text { LINK Byng } 2004\end{array}$ & Druss 2001 & Gilmer 2010 \\
\hline Process of care & $\begin{array}{l}\text { Specialty mental health } \\
\text { team (.5 fulltime- } \\
\text { equivalent (FTE) nurse } \\
\text { and a . } 25 \mathrm{FTE} \\
\text { psychiatrist) }\end{array}$ & $\begin{array}{c}\text { Nurse care managers } \\
\text { with at least } 5 \text { years } \\
\text { of clinical psychiatric } \\
\text { experience }\end{array}$ & $\begin{array}{l}\text { Assertive } \\
\text { Community } \\
\text { Treatment, family } \\
\text { treatment and } \\
\text { social skills } \\
\text { training }\end{array}$ & $\begin{array}{c}\text { Facilitation based QI } \\
\text { programme designed } \\
\text { to improve } \\
\text { communication } \\
\text { between general } \\
\text { practice and } \\
\text { community mental } \\
\text { health and improve } \\
\text { systems of care } \\
\text { within general } \\
\text { practice (including } \\
\text { roles of link worker } \\
\text { and psychiatrist) }\end{array}$ & $\begin{array}{l}\text { Integrated } \\
\text { primary care } \\
\text { and mental } \\
\text { health clinic }\end{array}$ & $\begin{array}{c}\text { Full service } \\
\text { partnerships and } \\
\text { subsidised housing } \\
\text { and full fidelity } \\
\text { Assertive Community } \\
\text { Treatment by team- } \\
\text { based services with } \\
\text { focus on } \\
\text { rehabilitation and } \\
\text { recovery }\end{array}$ \\
\hline Condition & $\begin{array}{l}\text { Bipolar disorder and } \\
\text { associated co- } \\
\text { morbidities including: } \\
\text { substance use } \\
\text { disorders, anxiety } \\
\text { disorders, any current } \\
\text { psychiatric co- } \\
\text { morbidity and active } \\
\text { medical co-morbidity } \\
\text { requiring treatment }\end{array}$ & $\begin{array}{c}\text { Bipolar spectrum } \\
\text { disorder diagnosed } \\
\text { during previous } 12 \\
\text { months (bipolar } \\
\text { disorder type I or } \\
\text { type II, } \\
\text { schizoaffective } \\
\text { disorder, or } \\
\text { cyclothymia). }\end{array}$ & $\begin{array}{l}1^{\text {st }} \text { episode } \\
\text { psychosis }\end{array}$ & $\begin{array}{l}\text { Long term mental } \\
\text { illness - chronic } \\
\text { psychosis, and } \\
\text { disabling neuroses }\end{array}$ & $\begin{array}{c}\text { SMI \& } \\
\text { homeless; co- } \\
\text { morbid drug } \\
\text { and alcohol } \\
\text { abuse. }\end{array}$ & $\begin{array}{l}\text { SMI (schizophrenia, } \\
\text { bipolar disorder, or } \\
\text { major depression) }\end{array}$ \\
\hline $\begin{array}{l}\text { Length of } \\
\text { follow up }\end{array}$ & 3 years & 2 years & 2 and 5 years & 1 year & 1 year & 2 years \\
\hline Screening & yes & yes & yes & yes & no & unclear \\
\hline $\begin{array}{l}\text { Additional } \\
\text { training for staff }\end{array}$ & yes & yes & $\begin{array}{l}\text { yes - staffed } \\
\text { trained to deliver } \\
\text { early intervention } \\
\text { program }\end{array}$ & $\begin{array}{l}\text { yes - training of } \\
\text { research facilitators }\end{array}$ & no & no \\
\hline $\begin{array}{l}\text { Treatment } \\
\text { algorithm }\end{array}$ & $\begin{array}{l}\text { yes - used to promote } \\
\text { identification and } \\
\text { treatment by outlining } \\
\text { medications to use } \\
\text { without sequencing } \\
\text { individual agents }\end{array}$ & yes & no & no & no & unclear \\
\hline $\begin{array}{l}\text { Formal stepped } \\
\text { care }\end{array}$ & no & yes & $\begin{array}{c}\text { no - team } \\
\text { assessed as to } \\
\text { when patients } \\
\text { were ready for a } \\
\text { specific treatment } \\
\text { modality }\end{array}$ & no & no & unclear \\
\hline $\begin{array}{l}\text { Enhanced } \\
\text { communication } \\
\text { between health } \\
\text { providers }\end{array}$ & no & $\begin{array}{l}\text { yes- contact tracking, } \\
\text { structured } \\
\text { assessment, and } \\
\text { standardised } \\
\text { feedback reports to } \\
\text { providers }\end{array}$ & unclear & $\begin{array}{l}\text { yes - formal } \\
\text { communication } \\
\text { guidelines around } \\
\text { referral, discharge } \\
\text { and professional roles } \\
\text { and patient } \\
\text { management }\end{array}$ & $\begin{array}{l}\text { yes - e-mail, } \\
\text { telephone, and } \\
\text { face-to-face } \\
\text { discussion }\end{array}$ & unclear \\
\hline $\begin{array}{l}\text { Care } \\
\text { management } \\
\text { location }\end{array}$ & outpatient clinic & $\begin{array}{c}\text { behavioural health } \\
\text { clinics }\end{array}$ & $\begin{array}{l}\text { primary care office } \\
\text { or in patient's } \\
\text { home or other } \\
\text { places in the } \\
\text { community }\end{array}$ & general practice & $\begin{array}{l}\text { primary care } \\
\text { clinic and } \\
\text { mental health } \\
\text { clinic adjoining }\end{array}$ & community \\
\hline $\begin{array}{l}\text { Patient } \\
\text { education/self } \\
\text { management }\end{array}$ & yes & yes & $\begin{array}{l}\text { yes - focus on } \\
\text { problem solving } \\
\text { and development } \\
\text { of skills to cope } \\
\text { with illness }\end{array}$ & no & yes & no \\
\hline $\begin{array}{l}\text { Case } \\
\text { management }\end{array}$ & yes & yes & yes- team based & yes & yes & yes \\
\hline
\end{tabular}


Table 3 The core components of shared care models for severe and persistent mental disorders (Continued)

\begin{tabular}{|c|c|c|c|c|c|c|}
\hline $\begin{array}{l}\text { Specialist } \\
\text { supervision }\end{array}$ & yes & yes - weekly & yes & yes & yes & yes \\
\hline $\begin{array}{l}\text { Care } \\
\text { coordination }\end{array}$ & $\begin{array}{c}\text { yes - scheduling } \\
\text { appointments and } \\
\text { follow-up for missed } \\
\text { appointments, and } \\
\text { with mental health } \\
\text { and medical-surgical } \\
\text { providers }\end{array}$ & yes & $\begin{array}{c}\text { yes - across team } \\
\text { and social services } \\
\text { and other } \\
\text { involved } \\
\text { institutions }\end{array}$ & yes & $\begin{array}{l}\text { yes - } \\
\text { scheduling } \\
\text { appointments } \\
\text { and follow-up } \\
\text { of missed } \\
\text { appointments } \\
\text { between the } \\
\text { two clinics }\end{array}$ & unclear \\
\hline $\begin{array}{l}\text { Follow up } \\
\text { provided to } \\
\text { patient }\end{array}$ & yes & yes & yes & yes & yes & yes \\
\hline Crisis support & yes & yes & $\begin{array}{l}\text { yes - crisis plan } \\
\text { developed with } \\
\text { each patient. } \\
\text { Patients given out } \\
\text { of hours contact } \\
\text { number for } \\
\text { response the } \\
\text { following day }\end{array}$ & unclear & unclear & yes - $24 / 7$ \\
\hline $\begin{array}{l}\text { Standardised } \\
\text { outcome } \\
\text { measure }\end{array}$ & yes & yes & yes & yes & yes & yes \\
\hline
\end{tabular}

have usually been well articulated clinical treatment models within an established theoretical framework such as Problem-Solving Therapy [33]. The evidence suggests that successful shared care requires a clear clinical focus tailored to the needs of particular conditions or patient subpopulations, specific selection of patients, coherent treatment models and agreed strategies to monitor treatment progress. These include, step-wise escalation and de-escalation of treatment intensity (type, frequency and duration) or urgency of response as needed and with mechanisms to ensure the maintenance of the necessary skills to deliver interventions [50,52,53] such as expert clinician supervision. Some studies also utilised patient education and self-management resources within stepped care intervention models. Some studies explicitly included patient treatment preferences [39]. This is an important feature since intervention studies need effective treatment options that are acceptable to consumers for broader implementation [54].

In contrast, studies of persistent and severe mental disorders such as schizophrenia have often entailed service brokerage and linkage interventions with less emphasis on particular therapeutic strategies or clearly articulated service models. Rather, they focus on the process and organisational aspects of care and ensuring engagement and communication across service sectors, such as housing, employment, hospital and communitybased care [20]. Studies in these populations also suggest that the benefits of specialist and primary care jointly working together are most evident when there is face to face contact with experienced mental health workers for case discussion than just case register or proactive recall strategies [44,51].

\section{Staff attributes and skill}

Fuller [18] found that the attributes and skills of staff were important and linkages were enhanced when key staff had experience in both mental health and primary care [55-57], and when clinical staff had a flexible work style that helped them to fit into a team $[55,58,59]$.The majority of studies targeting patients with persistent and severe mental illness, incorporated roles for identified mental health professionals, working within primary care to implement the shared care intervention with a range of tasks including care coordination, case review and liaison activities with primary care. Referred to in some instances as "link workers" [60], such roles were aimed to build "linkages" between primary care and specialist mental health services. Byng [60] found that the level of experience and flexibility of such specialist mental health link workers was important, particularly to achieve the benefits of their participation in face to face consultation for patients in "crisis". When staff doubted the value of a collaborative strategy, such as a formalised referral method, then this has resulted in low uptake of the strategy $[63,64]$.

While some studies suggest outcomes are better when care coordination is provided by mental health trained practitioners [17] others find that these skills can be developed by non-specialist health care providers if supported by training, regular case supervision and mentorship. These elements allow for direct patient 
Table 4 The core components of shared care models for severe and/or persistent mental disorders (contd)

\begin{tabular}{|c|c|c|c|c|c|c|}
\hline & $\begin{array}{l}\text { Harrison-Read } \\
2002\end{array}$ & Lester 2003 & $\begin{array}{l}\text { ACCESS } \\
\text { Rosenheck } \\
2002 \\
\end{array}$ & $\begin{array}{l}\text { Rosenheck } \\
2003\end{array}$ & van Orden 2009 & Warner 2000 \\
\hline Process of care & $\begin{array}{l}\text { Enhanced } \\
\text { Community } \\
\text { Management/ } \\
\text { Assertive } \\
\text { Community } \\
\text { Treatment }\end{array}$ & Patient-held record & $\begin{array}{l}\text { Integration of } \\
\text { service systems } \\
\text { with outreach } \\
\text { and case } \\
\text { management }\end{array}$ & $\begin{array}{l}\text { Housing }+ \\
\text { Intensive } \\
\text { Case } \\
\text { Management }\end{array}$ & $\begin{array}{l}\text { Collaborative care } \\
\text { involving access to } \\
\text { a mental health } \\
\text { worker in primary } \\
\text { care }\end{array}$ & Shared care record \\
\hline Condition & $\begin{array}{l}\text { "Heavy users" of } \\
\text { psychiatric } \\
\text { services }\end{array}$ & Schizophrenia & $\begin{array}{l}\text { SMI and } \\
\text { associated co- } \\
\text { morbidities + } \\
\text { homelessness }\end{array}$ & $\begin{array}{l}\text { Psychiatric } \\
\text { and/or } \\
\text { substance } \\
\text { abuse } \\
\text { disorders }\end{array}$ & $\begin{array}{l}\text { Mental disorder } \\
\text { (not described) }\end{array}$ & $\begin{array}{l}\text { Long term mental illness- } \\
\text { psychosis, personality } \\
\text { disorder or other condition } \\
\text { requiring long term } \\
\text { supervision }\end{array}$ \\
\hline $\begin{array}{l}\text { Length of } \\
\text { follow-up }\end{array}$ & 2 years & 1 year & 5 years & 1 year & 1 year & 1 year \\
\hline Screening & no & no & yes & unclear & yes & $\begin{array}{l}\text { Patients selected at } \\
\text { hospital discharge }\end{array}$ \\
\hline $\begin{array}{l}\text { Additional } \\
\text { training for staff }\end{array}$ & unclear & yes - in use of the record & $\begin{array}{l}\text { yes - inter- } \\
\text { agency }\end{array}$ & $\begin{array}{l}\text { yes - with } \\
\text { written } \\
\text { materials }\end{array}$ & & no \\
\hline $\begin{array}{l}\text { Treatment } \\
\text { algorithm }\end{array}$ & unclear & no & unclear & no & & no \\
\hline $\begin{array}{l}\text { Formal stepped } \\
\text { care }\end{array}$ & unclear & no & unclear & no & & no \\
\hline $\begin{array}{l}\text { Enhanced } \\
\text { communication } \\
\text { between health } \\
\text { providers }\end{array}$ & yes & $\begin{array}{l}\text { yes - shared care record } \\
\text { and flagging of patient } \\
\text { records in both general } \\
\text { practice and specialist } \\
\text { settings }\end{array}$ & yes & $\begin{array}{l}\text { yes - inter- } \\
\text { agency } \\
\text { agreement }\end{array}$ & yes & $\begin{array}{l}\text { yes - shared care record } \\
\text { linked to other } \\
\text { communication processes }\end{array}$ \\
\hline $\begin{array}{l}\text { Care } \\
\text { management } \\
\text { location }\end{array}$ & community & $\begin{array}{l}\text { general practice and } \\
\text { community }\end{array}$ & community & community & $\begin{array}{l}\text { general practice/ } \\
\text { primary care }\end{array}$ & $\begin{array}{l}\text { general practice and } \\
\text { community }\end{array}$ \\
\hline $\begin{array}{l}\text { Patient } \\
\text { education/self } \\
\text { management }\end{array}$ & unclear & no & unclear & no & yes - CBT & $\begin{array}{l}\text { no -instruction on use of } \\
\text { the booklet only }\end{array}$ \\
\hline $\begin{array}{l}\text { Case } \\
\text { management }\end{array}$ & yes & unclear & yes & yes & $?$ & unclear \\
\hline $\begin{array}{l}\text { Specialist } \\
\text { supervision }\end{array}$ & yes & unclear & yes & unclear & yes & unclear \\
\hline $\begin{array}{l}\text { Care } \\
\text { coordination }\end{array}$ & yes & unclear & yes & yes & no - referral only & unclear \\
\hline $\begin{array}{l}\text { Follow up } \\
\text { provided to } \\
\text { patient }\end{array}$ & unclear & unclear & yes & unclear & unclear & unclear \\
\hline Crisis support & no & unclear & unclear & yes & unclear & unclear \\
\hline $\begin{array}{l}\text { Standardised } \\
\text { outcome } \\
\text { measure }\end{array}$ & yes & yes & yes & yes & yes & yes \\
\hline
\end{tabular}

consultation by specialists if needed $[61,62]$ or for face to face consultation between primary care and specialist clinicians when needed [21].

While the need to increase the supply of mental health professionals is widely accepted, in some instances evidence suggests that efficient and effective use of specialists can support integrated delivery of care within primary health care sector. Improving the confidence, capacity and engagement of primary care clinicians in mental health care does however require attention to their support, training and supervision and to the attitudinal barriers to mental health service provision [63]. Jointly managed and funded collaborative care arrangements may help to address these barriers. This can be achieved while retaining the capacity to respond to the needs of the most complex patient [6]. 


\section{Purposively designed care delivery system}

Butler [64] noted that most trials of collaborative care built on the Chronic Care Model [65] include self-management support, a purposively designed care delivery system, decision support tools and a clinical information system.It is interesting to note the findings from a "Realistic Evaluation" of the UK-based program established by [51], which reveals the importance of contextual factors in tailoring the intervention to local needs, based on a mixture of fixed and flexible components that enabled a shared care agreement that reflected the local context. It is also interesting to note that electronic data register systems were perceived as less important in achieving the goals of this shared care intervention. Findings from this study suggest that so-called "catalyzing" functions (i.e. the integration of a mental health link worker into the primary care team, and facilitated planning) and "doing" (e.g. face to face discussion of patients and provision of advice when required,) were more effective than interventions based on improving information technology [60].

\section{Clarity of roles}

Role clarity is an important component of collaborative development and sustainability [23,66]. Yaffe [67] found that in $40 \%$ of cases primary care and mental health clinicians disagreed about the responsibility for and purpose of a referral (i.e. whether to assess or to treat). In the IMPACT study on depression, team and worker role clarification was used to identify safe practice boundaries [56].

\section{Leadership and governance}

Butler noted that overcoming local organisational and cultural barriers requires strong leadership to champion change [5].Shared governance arrangements between primary care and specialist services were found to support faithful application of evidence-based shared care models $[60,68,69]$. Such clinical governance was needed to promote (1) clear, agreed lines of clinical accountability, (2) clinically appropriate interventions linked with clear methods to ensure appropriate clinical supervision of staff $[17,70]$, and (3) appropriate evaluation of the "shared care" model $[17,39,50,52]$. Formal service agreements were found to build organisational support for "shared care". In several trials this was an important means to establish a mandate, change leadership and provide resources for integration [55,57,71-73].

\section{Funding}

The ACCESS trial found that mental health and human services that received direct funding and technical support achieved better integration [74], while Butler [64] described financial and organisational barriers to collaborative service arrangements including: the lack of reimbursement for activities such as care planning with other providers, and the restrictive rules imposed when combining funds from different sources; difficulties employing staff with the skills for new roles crossing mental health and primary care; and the costs of collaboration.

In most studies the research provided additional staffing and organisational infrastructure that was "grafted" onto existing services, with some service re-orientation. However, some small effectiveness trials did provide a more robust "bridge" to routine practice by utilising existing staff and resources [22,53] such as identification of mental health link workers, with researchers providing facilitation, tools and limited funding to support project implementation [21].

\section{Physical infrastructure}

Physical infrastructure was also important. The provision of co-located accommodation was an enabler of collaboration, when mental health care managers were located in the primary care clinic enabling optimum team visibility and interaction [56], but a barrier when clinic accommodation was inadequate [75]. Interestingly low uptake of quality improvement (QI) programs designed to increase collaboration between primary care and other specialist mental health and community mental health services has been attributed to a lack of face to face contact between primary care and mental health specialists [65].

\section{Feedback about outcomes}

In the IMPACT study [56,71]"the most important factor, cited in four of the five sites, was the ability to document positive client outcomes from the research study". Mechanisms to feedback evidence of outcomes to team staff seems to have been a key contributor to developing and sustaining service collaboration in this study, however the value of this process was not reported more widely in the other reviewed studies.

\section{Discussion}

"Shared Care" between specialist and generalist services has been a major focus of mental health service reforms. The purpose of this rapid review was to examine published evidence about models of shared care in mental health with specific attention to the core ingredients and processes necessary to support effective shared care models. The available evidence suggests that models of "shared care" between primary health services and specialist mental health service can lead to improved clinical outcomes in some clinical groups, such as depression and anxiety disorders. There is a small amount of evidence that shared care can provide better outcomes for people with psychoses and related disorders, such as reduced relapse rates. The complexity of the systems of care necessary for people with these disorders, may explain the limited evidence for shared care in this setting. 
The literature to date has used inconsistent definition of shared care; hence it is not surprising that it is difficult to distil core elements of effective care from existing studies. Furthermore the majority of the evidence is drawn from studies addressing depression and anxiety. There is less evidence regarding shared care in severe and persistent mental disorders and we cannot readily assume that models developed for the former will work with the latter.

On the basis of this rapid review we deduced a number of core ingredients of effective shared care models. These comprise provision of collaborative care in a coherent, evidence-based clinical management framework with:

i) A systematic approach to the engagement of primary and specialist services towards the common goal of improved mental health care

ii) A coherent treatment model relating to the target condition/s or patient population,

iii) An agreed clinical pathway and monitoring of patient outcomes with the provision of case review by specialist personnel when needed

iv) Attention to staffing requirements and the provision of clinical supervision to support skill development and maintenance of treatment model [50,53].

v) A well-established clinical governance framework.

In studies of shared care for people with persistent and severe mental disorders, a common element was the provision a care coordinator acting as a link between primary care and specialist mental health services.

A broader issue is the challenge of the translation of evidence into clinical practice. The gap between evidencebased care and clinical practice is widely acknowledged. While many studies demonstrate the benefits of multicomponent interventions for patient outcomes, service use and cost, there is less evidence about the successful implementation of such models into routine care. Changing clinician behaviour (within both primary care and specialist sectors) and maintaining systems that support and promote such changes is believed to be key to the implementation of new models of care [76]. The "voltage loss" over time of such interventions is a clear risk [50].

There are a number of important limitations to this review. A number of compromises to standard methods for systematic review were made. The shortened timescale did not permit activities to be undertaken sequentially and so activities overlapped and material was analysed as it became available. We were only able to examine a small selection of local grey literature. Particular importance was placed on published systematic reviews and the search focussed on key questions that were not addressed in those reviews, chiefly shared care for those with severe and persistent mental disorders.
Despite these limitations we attempted to ensure high standards of replicability and transparency through defined inclusion and exclusion criteria [4] as detailed in Additional file 2.

It was not possible to undertake meta-analytic evaluation of the strength of evidence as studies investigated complex interventions, with varying levels of attention to the methodological and statistical issues [77]. Second, while papers often focused on specific desirable clinical outcomes, a detailed description of the service implementation process was often poorly reported. This is a key requirement for the translation of such findings to practice.

\section{Conclusions}

From many angles, it is imperative to improve the links between primary care and specialist mental health services. When joint primary and specialist level collaborative care models have been evaluated using RCT designs, a range of clinical and service benefits are reported, particularly in the primary care management of depression and anxiety disorders.

The available evidence provides only limited support for shared care models for the treatment of persistent psychotic disorders. While a few robust and innovative studies have been undertaken with this population further studies are needed, including research that encompasses diverse geographic and health service contexts.

Some core components of shared care warrant further targeted research (e.g. the specific functions and roles of mental health linkage workers). Demonstration projects with detailed and innovative evaluative designs are needed to understand better these core elements and the processes that underpin effective shared care, particularly their capacity to be translated to routine clinical practice.

The strategies proposed in this review pose substantial implementation challenges for any health service, yet are critical to ensuring that shared care services are better structured to achieve sustained improvements in mental health care.

\section{Additional material}

Additional file 1: Search Strategy for Medline. Detail of

comprehensive search strategy for this review.

Additional file 2: Exclusion and Inclusion Criteria. Detail of specific criteria for papers included in this search.

\section{Acknowledgements}

The review was funded by NSW Department of Health (Office of Mental Health and Drug and Alcohol), through the Sax Institute NSW, Australia.

\section{Author details}

${ }^{1}$ Centre for Brain and Mental Health Research, School of Medicine and Public Health, Faculty of Health University of Newcastle, University Drive, Callaghan 
2308, Australia. ${ }^{2}$ School of Nursing \& Midwifery, Flinders University, Sturt Rd, Bedford Park 5024, Australia. ${ }^{3}$ Centre for Remote Health Research, Broken Hill University Department of Rural Health, University of Sydney, Corrindah Court, Broken Hill 2880, Australia.

\section{Authors' contributions}

BK led the preparation of the manuscript, participated in review of studies, collation and interpretation of findings. DP contributed to the manuscript, led the project team, and participated in review of studies, collation and interpretation of findings. JF contributed to the manuscript, participated in the review of studies, collation and interpretation of findings. SP designed the search strategy and conducted the literature searches, was responsible for data extraction and data management. She contributed to the interpretation of the findings and the drafting of the manuscript. All of the listed authors have read and approved the final manuscript.

\section{Competing interests}

The authors declare that they have no competing interests.

Received: 14 June 2011 Accepted: 21 November 2011

Published: 21 November 2011

\section{References}

1. New South Wales Mental Health Sentinel Events Review Committee: Tracking Tragedy. A systemic look at homicide and non-fatal serious injury by mental health patients, and suicide death of mental health inpatients. Fourth Report of the Committee 2008.

2. Armstrong R, Waters E, Roberts H, Oliver S, Popay J: The role and theoretical evolution of knowledge translations and exchange in public health. Journal of Public Health 2006, 28(4):384-89.

3. Gannan R, Ciliska D, Thomas H: Expediting systematic reviews: methods and implications of rapid reviews. Implementation Science 2010, 5(56).

4. Abrami PC, Borokhovski E, Bernerd R, Wade CA, Tamim R, Persson T, et al: Issues in conducting and disseminating brief reviews of evidence. Evidence and Policy 2010, 6(3):371-89.

5. Butler G, Deaton S, Hodgkinson J, Holmes ESM: Quick but not dirty: rapid evidence assessments as a decision support tool in social policy Government Social Research Unit, 2005. London; 2005.

6. Bower P, Gilbody S: Managing common mental health disorders in primary care: conceptual models and evidence base. British Medical Journal 2005, 330:839-42

7. Cape J, Whittington C, Bower P: What is the role of consultation-liaison psychiatry in the management of depression in primary care? A systematic review and meta-analysis. General Hospital Psychiatry 2010, 32:246-54.

8. Meadows G, Harvey C, Joubert L, Barton D, Bedi G: The ConsultationLiaison in Primary-Care Psychiatry program: A structured approach to long-term collaboration. Psychiatric Services 2007, 58(8):1036-38.

9. Lester H: Shared care for people with mental illness:a GP's perspective. Advances in Psychiatric Treatment (2005) 2005, 11:133-41.

10. Fuller J, Perkins D, Parker S, Holdsworth L, Kelly B, Frager L, et al: Systematic Review on Service Linkages in Primary Mental Health Care: Informing Australian policy and practice Australian Primary Health Care Research Institute. Canberra; 2009.

11. Smith SM, Allwright S, O'Dowd T: Effectiveness of shared care across the interface between primary and specialty care in chronic disease management. Cochrane Database of Systematic Reviews 2007, , 3: CD004910.

12. Kates N, Ackerman S: Shared Mental Health Care in Canada. A Compendium of Current Projects. 1997.

13. Penrose-Wall J: Dissemination Report of the Illicit Drug Shared Care Project Centre for General Practice Integration Studies; 2002.

14. Foy R, Hempel S, Rubenstein L, Suttorp M, Seelig M, Shanman R, et al: Meta-analysis: effect of interactive communication between collaborating primary care physicians and specialists. Annals of Internal Medicine 2010, 152(4):247-58.

15. Bower P, Gilbody S, Richards D, Fletcher J, Sutton A: Collaborative care for depression in primary care. Making sense of a complex intervention: systematic review and meta-regression. British Journal of Psychiatry 2006, 189:484-93.
16. Craven M, Bland R: Better practices in collaborative mental health care: an analysis of the evidence base. Canadian Journal of Psychiatry 2006, 51(6 Suppl 1):7S-72S.

17. Gilbody S, Bower P, Fletcher J, Richards D, Sutton A: Collaborative care for depression: a cumulative meta-analysis and review of longer-term outcomes. Archives of Internal Medicine 2006, 166(21):2314-21.

18. Fuller J, Perkins D, Parker S, Holdsworth L, Kelly B, Roberts R, et al: Building effective service linkages in primary mental health care: a narrative systematic review part 2. BMC Health Services Research 2011, 11(66).

19. Fuller J, Perkins D, Parker S, Holdsworth L, Kelly B, Roberts R, et al: Effectiveness of service linkages in primary mental health care: a narrative systematic review part 1. BMC Health Services Research 2011, 11(72).

20. Bauer M, Biswas K, Kilbourne A: Enhancing multiyear guideline concordance for bipolar disorder through collaborative care. American Journal of Psychiatry 2009, 166(11):1244-50.

21. Simon G, Ludman E, Bauer M, Unutzer J, Operskalski B: Long-term effectiveness and cost of a systematic care program for bipolar disorder. Archives of General Psychiatry 2006, 63(5):500-8.

22. Byng R, Jones R, Leese M, Hamilton B, McCrone P, Craig T: Exploratory cluster randomised controlled trial of shared care development for longterm mental illness. British Journal of General Practice 2004, 54(501):259-66.

23. Druss BG, Rohrbaugh RM, Levinson CM, Rosenheck R: Integrated medical care for patients with serious psychiatric illness: a randomized trial. Archives of General Psychiatry 2001, 58(9):861-8.

24. Gilmer T, Stefancic A, Ettner S, Manning W, Tsemberis S: Effect of fullservice partnerships on homelessness, use and costs of mental health services, and quality of life among adults with serious mental illness. Archives of General Psychiatry 2010, 67(6):645-52.

25. Harrison-Read P, Lucas B, Tyrer P, Ray J, Shipley K, Simmonds S, et al: Heavy users of acute psychiatric beds: randomized controlled trial of enhanced community management in an outer London borough. Psychological Medicine 2002, 32(3):403-16.

26. Lester H, Allan T, Wilson S, Jowett $S$, Roberts L: A cluster randomised controlled trial of patient-held medical records for people with schizophrenia receiving shared care. British Journal of General Practice 2003, 53(488):197-203.

27. Rosenheck R, Kasprow W, Frisman L, Liu-Mares W: Cost-effectiveness of supported housing for homeless persons with mental illness. Archives of General Psychiatry 2003, 60(9):940-51.

28. Rosenheck R, Lam J, Morrissey J, Calloway M, Stolar M, Randolph F: Overview of the ACCESS Program. Psychiatric Services 2002, 53(8):958-66.

29. van Orden M, Hoffman T, Haffmans J, Spinhoven P, Hoencamp E: Collaborative Mental Health Care Versus Care as Usual in a Primary Care Setting: A Randomized Controlled Trial. Psychiatric Services 2009, 60(1):74-79.

30. Bertelsen M, Jeppesen P, Petersen L, Thorup A, Ohlenschlaeger J, le Quach P, et al: Five-year follow-up of a randomized multicenter trial of intensive early intervention vs standard treatment for patients with a first episode of psychotic illness: the OPUS trial. Archives of General Psychiatry 2008, 65(7):762-71.

31. National Health and Medical Research Council: How to review the evidence: systematic identification and review of the scientific literature Canberra; 2000.

32. Alexopoulos GS, Katz I, Bruce M, Moonseong H, Ten Have T, Patrick R, et al: Remission in Depressed Geriatric Primary Care Patients: A Report From the PROSPECT Study. The American Journal of Psychiatry 2005, 162(4):718.

33. Unutzer J, Katon W, Callahan C, Williams J, Hunkeler E, Harpole L, et al: Collaborative care management of late-life depression in the primary care setting: a randomized controlled trial.[see comment]. JAMA 2002, 288(22):2836-45.

34. Katon W, Von Korff M, Lin E, Simon G, Walker E, Unutzer J: Stepped collaborative care for primary care patients with persistent symptoms of depression: a randomized trial. Archives of General Psychiatry 1999, 56(12):1109-15.

35. Katon W, Rutter C, Ludman E, Von Korff M, Lin E, Simon G: A randomized trial of relapse prevention of depression in primary care. Archives of General Psychiatry 2001, 58(3):241-7.

36. Katon W, Von Korff M, Lin E, Simon G, Ludman E, Russo J, et al: The Pathways Study: A Randomized Controlled Trial of Collaborative Care in Patients with Diabetes and Depression. Archives of General Psychiatry 2004, 61:1042-9. 
37. Llewellyn-Jones R, Baikie K, Smithers H, Cohen J, Snowdon J, Tennant C: Multifaceted shared care intervention for late life depression in residential care: randomised controlled trial. British Medical Journal 1999, 319(7211):676-82.

38. Swindle RW, Rao JK, Helmy A, Plue L, Zhou XH, Eckert GJ: Integrating clinical nurse specialists into the treatment of primary care patients with depression. International Journal of Psychiatry in Medicine 2003, 33(1):17-37.

39. Roy-Byrne P, Craske M, Sullivan G, Rose R, Edlund M, Lang A, et al: Delivery of Evidence-Based Treatment for Multiple Anxiety Disorders in primary Care: A Randomised Controlled Trial. JAMA 2010, 303(19):1921-28.

40. Arean PA, Ayalon L, Hunkeler E, Lin EHB, Tang L, Harpole L, et al: Improving depression care for older, minority patients in primary care. Medical Care 2005, 43(4):381-90.

41. Arean PA, Ayalon L, Jin C, McCulloch CE, Linkins K, Chen $\mathrm{H}$, et al: Integrated specialty mental health care among older minorities improves access but not outcomes: results of the PRISMe study. International Journal of Geriatric Psychiatry 2008, 23(10):1086-92.

42. Griswold K, Zayas L, Pastore P, Smith S, Wagner C, Servoss T: Primary care after psychiatric crisis: a qualitative analysis. Annals of Family Medicine 2008, 6(1):38-43.

43. Warner J, King M, Blizard R, McClenahan Z, Tang S: Patient-held shared care records for individuals with mental illness: Randomised controlled evaluation. British Journal of Psychiatry 2000, 177:319-24.

44. McDonough M, Thornicroft G, Barclay W, DeWet C, Kalidindi S, O'Brien T: Costs and benefits of a pilot shared care register between primary and secondary healthcare for patients with psychotic disorders. Primary Care Mental Health 2003, 1(1):55-62.

45. Brown J, Afuwape S, Downes-Grainger E, Howells R, Cole E, Goldberg S: Organising community mental health teams around GP practices: GPs' responses to the linkworker model. Primary Care Psychiatry 2004 9(2):45-50.

46. Hull SA, Jones C, Tissier J, Eldridge S, Maclaren D: Relationship style between GPs and community mental health teams affects referral rates. British Journal of General Practice 2002, 52(475):101-7.

47. Bauer M, McBride L, Williford W, Glick H, Kinosian B, Altshuler L, et al: Collaborative care for bipolar disorder: part I. Intervention and implementation in a randomized effectiveness trial. Psychiatric Services 2006, 57(7):927-36, a

48. Bauer M, McBride L, Williford W, Glick H, Kinosian B, Altshuler L, et al: Collaborative care for bipolar disorder: Part II. Impact on clinical outcome, function, and costs. Psychiatric Services 2006, 57(7):937-45, b.

49. Chomik T: A Report on Shared Care - (Part of the Primary Health Care Shared Care Network Development Initiative) Provincial Health Services Authority; 2005

50. Oxman $\mathrm{T}$, Dietrich $\mathrm{A}$, Schulberg $\mathrm{H}$ : The depression care manager and mental health specialist as collaborators within primary care. The American Journal of Geriatric Psychiatry 2003, 11(5):507.

51. Byng R, Norman I, Redfern SRJ: Exposing the key functions of a complex intervention for shared care in mental health: case study of a process evaluation. BMC Health Services Research 2008, 8(274).

52. Unutzer J, Schoenbaum M, Druss BG, Katon W: Transforming Mental Health Care at the Interface With General Medicine: Report for the President's Commission. Psychiatric Services 2006, 57(1):37-47.

53. Dietrich A, Oxman T, Williams J, Schulberg $H$, Bruce $M$, Lee $P$, et al: Reengineering systems for the treatment of depression in primary care: cluster randomised controlled trial. BMJ 2004, 329(7466):602.

54. Howard L, Thornicroft G: Patient preference randomised controlled trials in mental health research. British Journal of Psychiatry 2006, 188:303-04.

55. Kirchner J, Cody M, Thrush C, Sullivan G, Rapp C: Identifying factors critical to implementation of integrated mental health services in rural VA community-based outpatient clinics. Journal of Behavioral Health Services \& Research 2004, 31(1):13-25.

56. Oishi SM, Shoai R, Katon W, Callahan C, Unutzer J: Impacting late life depression: Integrating a depression intervention into primary care. Psychiatric Quarterly 2003, 74(1):75-89.

57. Byng R, Norman I, Redfern S: Using Realistic Evaluation to Evaluate a Practice-level Intervention to Improve Primary Healthcare for Patients with Long-term Mental Illness. Evaluation: The International Journal of Theory, Research and Practice 2005, 11(1):69-93

58. Kates N: Shared mental health care. The way ahead. Canadian Family Physician 2002, 48(MAY):853-55
59. Pirkis J, Livingston J, Herrman H, Schweitzer I, Gill L, Morley B, et al: Improving collaboration between private psychiatrists, the public mental health sector and general practitioners: evaluation of the Partnership Project. Australian \& New Zealand Journal of Psychiatry 2004, 38(3):125-34.

60. Byng Richard, Norman lan, Redfern Sally, Jones R: Exposing the key functions of a complex intervention for shared care in mental health: case study of a process evaluation. BMC Health Services Research 2008, 8(274).

61. Strong V, Waters R, Hibberd C, Murray G, Wall L, Walker J, et al: Management of depression for people with cancer (SMaRT oncology 1): a randomised trial. Lancet 2008 2008, 372:40-48.

62. Rahman A, Malik A, Sikander S, Roberts C, Creed F: Cognitive behaviour therapy-based intervention by community health workers for mothers with depression and their infants in rural Pakistan: a cluster-randomised controlled trial. Lancet 2008, 372:902-9.

63. Oakley Browne M, Lee A, Prabhu R: Self-reported confidence and skills of general practitioners in management of mental health disorders. Australian Journalof Rural Health 2007, 15:321-26.

64. Butler M, Kane RL, McAlpine D, Kathol R, Fu SS, Hagedorn $H$, et al: Integration of mental health/substance abuse and primary care. Health Technology Assessment Database 2008, 1.

65. Wagner E, Austin B, Von Korff M: Organizing Care for Patients with Chronic Illness. Milbank Quarterly 1996, 74(4):511-44.

66. Fickel J, Parker L, Yano E, Kirchner J: Primary care - mental health collaboration: an example of assessing usual practice and potential barriers. Journal of Interprofessional Care 2007, 21(2):207-16.

67. Yaffe M, Primeau F, McCusker J, Cole M, Belzile E, Dendukuri N, et a: Psychiatric outpatient consultation for seniors. Perspectives of family physicians, consultants, and patients/family: A descriptive study. BMC Family Practice 2005, 6(15)

68. Tansella M, Thornicroft G: Implementation science: understanding the translation of evidence into practice. The British Journal of Psychiatry 2009, 195:283-85.

69. Forsner T: Implementing clinical guidelines in psychiatry:a qualitative study of perceived facilitators and barriers. BMC Psychiatry 2010, 10(8)

70. Lesage A, Seguin M, Guy A, Daigle F, Bayle M, Chawky M, et al: Systematic Services Audit of Consecutive Suicides in New Brunswick: The Case for Coordinating Specialist Mental Health and Addiction Services. Canadian Journal of Psychiatry 2008, 53(10):671.

71. Blasinsky M, Goldman H, Unutzer J: Project IMPACT: a report on barriers and facilitators to sustainability. Administration \& Policy in Mental Health 2006, 33(6):718-29

72. Rees G, Huby G, McDade L, McKechnie L: Joint working in community mental health teams: implementation of an integrated care pathway. Health \& Social Care in the Community 2004, 12(6):527-36

73. Richards D, Lankshear A, Fletcher J, Rogers A, Barkham M, Bower P: Developing a U.K. protocol for collaborative care: a qualitative study. General Hospital Psychiatry 2006, 28(4):296-305

74. Morrissey J, Calloway M, Thakur N, Cocozza J, Steadman H, Dennis D: Integration of service systems for homeless persons with serious mental illness through the ACCESS program. Access to Community Care and Effective Services and Supports.[see comment]. Psychiatric Services 2002, 53(8):949-57.

75. Macdonald W, Bradley S, Bower P, Kramer T, Sibbald B, Garralda E, et al: Primary mental health workers in child and adolescent mental health services. Journal of Advanced Nursing 2004, 46(1):78-87.

76. Woolf $\mathrm{SH}$ : The meaning of translational research and why it matters. JAMA 2008, 299(2):211-13.

77. Medical Research Council: Developing and evaluating complex interventions Medical Research Council. London; 2008.

doi:10.1186/1752-4458-5-31

Cite this article as: Kelly et al:: Shared care in mental illness: A rapid review to inform implementation. International Journal of Mental Health Systems 2011 5:31. 